\title{
Post-War Resettlement and Urban Reconstruction: A case study of Khorram-Shahr, Iran
}

\author{
${ }^{1}$ Mirisaee, S.M ${ }^{*},{ }^{2} \mathrm{lbrahim}, \mathrm{M} . \mathrm{A} \&{ }^{3}$ Faizah, A. \\ ${ }^{123}$ Department of Urban and Regional Planning, University of Malaya, Kuala Lumpur, 50603, Malaysia \\ *miresaiee@gmail.com
}

\begin{abstract}
The resettlement plan in war-torn cities is one of the most important objectives after conflict, as the ultimate goal is to repatriate immigrants and establish an ordinary life for residents. The resettlement plan plays a significant role in the reconstruction of urban areas in the post-war situation. This paper firstly review the literature on post-war resettlement process, then explore the resettlement strategy in the urban area of Khorram-Shahr as the most important war-torn city in Iran. The discussions are based on the results of a sequential mixed method (qualitative and quantitative) research exploring the persistent urban problems and local peoples' expectations in damaged neighbourhoods. The findings of this study reveal the most important strategies for resettlement in the post-war city to be considered by urban planners and authorities.
\end{abstract}

Keywords: Post-war reconstruction, war-ruined city; resettlement plan; urban reconstruction; KhorramShahr reconstruction

\section{INTRODUCTION}

It is not an exaggerated statement to say that urban warfare is the greatest man-made disaster that ruins buildings and urban space, which caused the displacement of urban residents. Post-war restoration aims to provide basic services and to help people to self-sufficiency and self-belief, and repair destruction, grant facilities and funding to provide material and supporting survivors in psychological and social aspects. The ultimate goal of resettlement is to provide living conditions for the survivors of the war and urban residents. Resettlement action as an important phase of the recovery process while war as a conflict causes many social and physical changes in people's day-today lives (Cuny et al., 1983; Geipel, 1991).

The plan of post-war rehabilitation in Iran was one of the prominent actions after the war. The IranIraq War (1980-1988), involved two great oil producers, was the second longest and one of the most strategically important conflicts in the twentieth century (Hilāl, 1981). During the eight years of the war, both countries suffered millions of casualties and lost billions of dollars. Over five million have also lost their homes and jobs, and 2.5 million (from both countries) have been forced to migrate to war-free zones where they live in refugee camps or selfprepared shacks (Amirahmadi, 1987). In terms of destruction, cities on both sides were destroyed by urban warfare, bombing and rocket attacks. This paper explored resettlement strategy based on the social and physical aspects of reconstruction in Khorram-Shahr the largest and most important occupied city during the War.

Twenty years after the war, urban areas of Khorram-Shahr still suffer from the scars of war, and the city's residents are struggling with a number of difficulties. A report by the Research Center of Parliament in Iran (2007) revealed that, of 16,000 damaged buildings, 6500 buildings remained ruined in Khorram-Shahr and nearby Adaban. These abandoned lands and dilapidated houses deform the urban shape and city landscape. The report stated that some damaged buildings have been left in that condition due to former residents not returning. This paper explores priorities of the post-war resettlement plan in Khorram-Shar then investigates persistent urban defects related to the resettlement strategy in the reconstruction process. 


\section{URBAN RESETTLEMENT: PROCESS AND COMPLICATIONS}

Post-war restoration involves the interrelated tasks of economic, political and social rehabilitation, since wars influence the social fabric as well as destroy the physical infrastructure (Kumar, 1997). Most of the definitions of "restoration" refer to the concept of returning something to its former position. The "the triple R" concept conveys that the tremendous task of restoration involves reconstruction, rehabilitation and reintegration, thus covering these three different fields (Bruchhaus, 2002). Post-war resettlement is a vital aspect of the restoration plan after conflicts, and the population displacement has an indirect effect on other social aspects such as crime and delinquency.

Because of the diverse aspects of wars, trusted longitudinal studies of post-war recovery processes are few, and a large number of war-torn sites have not yet been subject to formal analysis (Calame, 2005). Cuny et al. (1983) argue that the results of the restoration process in most disasters, regardless of their root causes, emerge through a recovery process with recognisable phases. They present a model for restoration after disaster in which the resettlement process starts in the rehabilitation phase, which is the phase between rescue and reconstruction. In this approach, the period immediately following a catastrophe is the emergency phase devoted to rescue, assessment and critical repairs to the infrastructure. In this model, the resettlement phase starts when residents return to normal patterns of work and social relations while permanent repairs to public utilities are undertaken. The United Nations (2008) highlights two general stages in the restoration phase after a disaster, namely, the emergency phase and the recovery phase. The emergency phase is the period during which individuals within the affected population are concerned primarily with survival. In the recovery phase, the displaced population is assisted in order to shorten the need for emergency shelter and move towards more durable housing solutions as quickly as possible. After emergency shelter, resettlement stage is implemented as a transitional stage in which the ultimate goal is to resume the normal patterns of work and social relations. Haas et al. (1977) group restoration actions in three categories, namely, recovery, transaction, and stabilisation. They argue that the duration of every stage of restoration is strongly related to the pre-disaster urban trends, the damage suffered, and the resources available for recovery. They demonstrate that the duration of every stage of restoration is a multiplicative factor of the emergency and restoration period whereby replacement reconstruction is the equivalent of one hundred times the emergency period and ten times the restoration period. The first need for urban resettlement is to provide general services and remake damaged infrastructure and destroyed buildings to replace and restore the situation to the pre-disaster state (Lizarralde et al., 2010). This cannot be delayed until all reconstruction aspects is provided in the damaged regions; therefore, returning to a post-war city implies returning to a society that is still under reconstruction (Pedersen, 2003).

The most important social problem of resettlement after war is migration and demographic change in the urban areas of post-war cities. Voluntary and compulsory migrations occur during wars due to the risks of occupation and mass urban destruction; migration then emerges as a social problem with a range of inseparable issues in post-war resettlement. Thus, the post-war progress of repatriation and demobilisation procedures is often cumbersome. For example, the large wave of displaced people settled in camps on the outskirts of Beirut due to the war in Lebanon: this population slowly needed housing as new residents of Beirut and was recognised during the process of urban development (Yassin, 2012). Pedersen (2003) describes the resettlement process in post-war cities as a significant effort in a society that is still under reconstruction. The post-war period involves rebuilding, which takes place in risky environments where peace and security can be slow to return, and the destruction and uprooting of populations are widespread (Bruchhaus, 2002). The return to a post-war city is gradual in different population groups. In general, post-war migrants are classified in three groups. The first group has migrated from their original homeland during a war and will eagerly return. The second group will not return to their homeland - they prefer to live in their new home. The third group comprises people from other parts of the country or region who come to the post-war city to find new opportunities; for example, by working in reconstruction activities (Rabani, 1997). Therefore, understanding the diverse range of residents' participation and expectations after a war is a crucial aspect in resettlement plans where the main target groups are the people who want to live in the reconstructed city.

\section{POST-WAR RECONSTRUCTION IN IRAN}

The most disadvantage of Iran-Iraq war, was dramatically decreased of living conditions in wartorn cities. Two-thirds of Iranian involved the negative effect of the war and numerous civilians were killed. Moreover about one million and 240 thousand forced to migrate from war torn cities (Rabani, 1997). 
Approximately, 250,000 of Iranian died in the warfare or by air raids and ballistic missile attacks. Government statistics held by the Headquarters of Reconstruction and Renovation of the War Region in Iran (Setade bazsazi manategh jangzade) reported that, among all 24 provinces of Iran, 16 provinces were involved in military attacks, and 328,340 residential and commercial buildings were damaged or ruined in 87 war-torn cities. In addition, a number of public services such as health and education institutions and cultural centers have encountered a lot of damage.

Khorram-Shahr was the largest and most important occupied city during the Iran-Iraq war. It was damaged, with 88 percent of buildings and infrastructure destroyed during the war, and it was unpopulated for almost seven years. The city of Khorram-Shahr had played a significant role in the trade and development for the country as the largest port in Iran before the war. In addition, the city was the gateway of Iran to the Persian Gulf from the sea and to Basra in Iraq from the road. The city reached to the highest peak of population by 150 thousand before the war (1977). The significant economic and urban growth dramatically crashed due to the war event in 1980 while the city was abandoned and de-populated for almost eight years. The number of residents came back to the pre-war situation; however, the country's population has doubled from 35 million to 75 million within three decades from 1980 to 2011 . According to Centre of Iran Census (2010) 30 percent of returnees were non-local people. Conferring to the comprehensive reconstruction plans for KhorramShahr after the city's liberty, a total of 18,710 commercial and housing buildings existed within the city. Two thousand of them were estimated to be completely destroyed, and the 16,000 remaining buildings were classified as damaged $(22 \%$ and $75 \%$, respectively). Next consequence of war that Iran deprived of is using the Arvand River for trading and transportation. It was occurring with the destruction of the Khorram-Shahr port and unsafe condition in the region.

Governments had created many new agencies concerned with war and reconstruction, including Ministry of Construction Crusade, Housing Foundation (Bouniud-e Muskun), Foundation for the Affairs of the War Immigrants and the Ministries of Housing and Urban Development. Reconstruction during the war commenced in five war-damaged provinces in order to achieve the integration of the urban population, prevent mass migration, and give confidence to the war victims. The first phase of the during-war reconstruction was effectively implemented in cities damaged by bombing. However, a number of cities, including Khorram-Shahr were not considered for during-war rehabilitation due to the risk of re-occupation. The main impetus for resettlement began after the war, in August 1988, when Iran turned its attention to the enormous task of reconstruction and took seven years up to 1995 (Hooglund, 1989).

Relocation was one of the proposed strategies for reconstruction plan of Khorram-Shahr. One of the options put forward by the government for rebuilding Khorram-Shahr was to build a new city in a safe place and transform the ruined city to a war museum (Rabani, 1997). A new location should be a place that has no existing environmental and geographical problems, and be suitable for future development (Najarian et al., 1996). However, most of the residents opposed this plan due to a sense of pre-war memories of the original place. Restoration of Khorram-Shahr in original place illustrates conflicts and misunderstandings between the central government in Tehran and local administration and authorities because the city lost its justification as a major port led to slow post-war rehabilitation in the city (Motawaf, 1989). Substitute ports had been developed in safer places during the war and two main pre-war prosperity aspects, namely, tourism and maritime trade of Khorram-Shahr, never returned to the previous situation. Alternative ports, including Bandaer-Imam and Bandare Abbas Ports, were developed with considerable investments after the war, and KhorramShahr Port was not able to recover its previous standing (Hooglund, 1989).

\section{METHODOLOGY}

The exploratory sequential mixed method approach was adopted for this paper, which began with expert interviews followed by a survey using a questionnaire (Creswell \& Clark, 2011). The expert interview initiates expands understanding, and is suitable to explore resettlement priorities in the post-war city (Knight \& Ruddok, 2008). The researcher adopted the purposive sampling for experts to contribute in semistructured interviews from organizations and subdivisions at various spatial levels of post-war reconstruction, housing and rehabilitation. Twelve experts in the field of urban areas were selected from Housing Foundation and Ministries of housing as two main departments in the reconstruction and resettlement plan in Iran. The experts are integrated in the research not as a single cause, but rather as representatives of a group which participated in the 
urban restoration process. According to the interview protocol, ten questions of the semi-structured interviews were designed to seek information about, firstly, social rehabilitation priorities after the war, secondly, existing problems after the post-war reconstruction, and thirdly, resident's participation and expectation of the implemented plan in the post-war city. Textual materials in the research were read, annotated and coded. Categories are generated from reading, annotating and evaluated in regard to the relevance of emerging taxonomy in relation to the empirical setting from which they emerged. The qualitative research methods were followed by selfadministered questionnaires to examine the views of local residents of two most destructed neighbourhoods of Khorram-Shahr. The effectiveness of policy and priorities in the resettlement process were examined through five-point Likert scale questions. The sample for the questionnaire was based on the purposive sampling method (Kerlinger \& Lee, 2000) contained the residents of two most damaged neighbourhoods in Khorram-Shahr, (Masjid Jame and Karoon Riverside Street). A total of 90 questionnaires were successfully completed by local residents who were living in the city during the reconstruction period (1988-1995) and have a personal or family background in the pre-war era.

\section{FINDINGS: RESETTLEMENT STRATEGY}

\subsection{SOCIAL PRIORITIES}

Most of the efforts to rebuild Khorram-Shahr after the war were focused on returning migrants to the abandoned city. Migrations into safe cities during the war caused socio-cultural changes and serious dilemmas for the host cities. To overcome social problems in the other cities, repatriations were the first priority to eliminate the crises created in the neighbouring provinces. One interview explained this problem as follows:

"To eliminate the crises in the neighbouring province repatriation [to Khorram-Shahr] was the first priority for government."

Khorram-Shahr residents constituted the country's largest number of long-term migrants. Most of the migrants had stable conditions as new residents in safe cities for eight years; therefore, some of them were not willing to return to Khorram-Shahr. The government rushed to push people back into border cities because of security concerns and to avoid the problem of empty border cities. One interview confirmed this view as follows:
"Borders should not depopulate, because of security reasons in ceasefire (no war and no peace) situation."

\subsection{PHYSICAL PRIORITIES AND CONSEQUENCES IN URBAN AREAS}

The first government strategy for the resettlement plan was rebuilding the essential infrastructure, housing and creating job opportunities for returnees. On that circumstance, quick physical reconstruction was the major aspects of the resettlement plan. This was confirmed by an interview as follows:

"Creating opportunities for people to return and settle within the city was the first priority for us to resettlement of returnees."

Two types of main physical priorities for resettlement were identified in Khorram-Shahr, namely, housing, and infrastructure. The housing sector was a major component of the plan. The Iranian Government did not relocate the city, but rather decided to reconstruct urban of Khorram-Shahr on its original site. Policies in relation to residential buildings were based on helping people to reconstruct or renovate damaged homes through access to government loans and grants. As one interviewee explained:

"Housing and supply infrastructure for resettlements like drinking water and electricity was the first priority after the war."

"Policy of housing reconstruction focused on quality supervision while construction delegated to the owners."

The government delegated housing reconstruction to the returned people. This policy of self-reconstruction caused some post-reconstruction problems. According to the experts, infrastructure also was the main concern in the early years of reconstruction. The vision for the infrastructure development during the early years during the reconstruction period was based on the vision that concentrated on reconstructing the essential infrastructure and utilities rather than development concerns. As one interview explained:

"The first priority for us was a restoration of water supply and electricity in the first two years of the reconstruction process."

There were two types of damaged infrastructures after the war in Khorram-Shahr. The first type was the infrastructure which provided essential needs for 
residents, in particular, drinking water and electricity. The second type was the infrastructures that did not have a direct or immediate effect on the urban life, including transportation and the harbour restoration. In the first three years of reconstruction, the government focused on the essential infrastructure, and any other development was postponed to the next phase of the plan. This was explained in the interviews as follows:

"We could not develop infrastructures during first phase of restoration because of unstable security condition in Khorram-Shahr"

After restoring the basic infrastructure, the government considered the rest of the infrastructure as the way to build prosperity in the future. As one interviewee explained, this included focusing on the port redevelopment:

"[The] harbour could play an important role of infrastructure restoration in the secondary phase of reconstruction to flourish pre-war era for resettlement."

The experts noted that the reconstruction planners regularly faced security caveats in the development of infrastructure. Developing infrastructure along the border before stable peace conditions had been established increased the barriers to reconstruction. The cautious approach to infrastructure development was justified in the early years of reconstruction; however, this approach continued and has now been implemented for over twenty years and creates disadvantages for the residents. The current position of the authorities is to explain that attention to physical reconstruction is inappropriate because the post-war reconstruction and development of infrastructure should be implemented based on a comprehensive development plan that considers the pre-war identity and future prospects of the city:

"Nowadays, we understand that providing essential infrastructure is not adequate for city development, while attending to the pre-war potentials needs to plan reconstruction policy."

The last part of interviews consisted of exploring urban problems related to implementation of the resettlement plan twenty years after implementation. The vast destruction of the urban fabric due to eight years of war was compounded by the urban problems during and after reconstruction in Khorram-Shahr. The expert viewpoints demonstrated that the disjunction between the building facades in Khorram-Shahr has arisen due to the contrast between newly-made, reconstructed and damaged buildings. The experts noted that the dispersion and different scales of destruction in the city led to the mismatch between the old and new buildings. This issue led the creation of a disproportionate urban facade in the city. The contrasts between the new and damaged buildings create a visually displeasing effect, particularly on the main streets where they are more exposed as the major component of the urban facade.

Although governments in some other countries have carried out mass house construction after a war, the Iranian Government had minimal participation in the implementation phase of housing reconstruction even though it is the most important priorities for resettlement plan. They delegated housing reconstruction to people, and this policy of selfreconstruction caused mentioned urban problems. Based on the interviews, urban defect outline in table 1 including category and code of physical, social and executive problems with samples of experts' quotes.

\subsection{RESIDENT EXPECTATION}

The effectiveness of policy and priorities in people's day-to-day lives in the resettlement process were examined through in the second phase of this paper. Most of the respondents selected the rank four indicating a "strong effect of reconstruction" for utilities and housing, making them the most important priorities for the reconstruction period. A total of $75 \%$ of the respondents scored utilities at rank four or five for the strength of the effect, while the second rank went to housing with $61 \%$ of importance.

Regarding the central tendency of mentioned priorities, the provision of utilities was the highest ranked priority, with a mean of $3.8(\mathrm{SD}=0.36)$ and a median of four. The second-ranked priority was housing with a slight gap behind utilities, with a mean of $3.56(\mathrm{SD}=0.59)$ and a median of four. The thirdranked priority was commercial units with a mean of $2.46(\mathrm{SD}=0.35)$ and a median of two. 
Table 1: Categories of persistent urban problem after reconstruction in Khorram-Shahr

\begin{tabular}{|c|c|c|c|}
\hline Theme & Category & Problem (code) & Sample of Quote \\
\hline \multirow{4}{*}{$\begin{array}{l}\text { Current Problems } \\
\text { in Urban Fabric } \\
\text { regarding to the } \\
\text { Post-war } \\
\text { Reconstruction }\end{array}$} & Physical & $\begin{array}{l}\text { Old buildings versus } \\
\text { new-made buildings }\end{array}$ & $\begin{array}{l}\text { 1- Sharp contrasts between old, new and } \\
\text { reconstructed buildings make } \\
\text { anomalies in urban facades. }\end{array}$ \\
\hline & Physical & $\begin{array}{l}\text { Abandoned land and } \\
\text { dilapidated buildings }\end{array}$ & 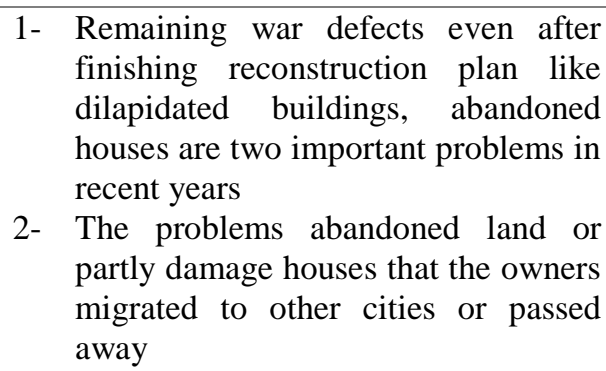 \\
\hline & Executive & $\begin{array}{l}\text { Implementation of } \\
\text { reconstruction plans } \\
\text { and undeveloped } \\
\text { infrastructures }\end{array}$ & $\begin{array}{l}\text { 1- Multiplicity and lack of coordination } \\
\text { in the implementation of } \\
\text { reconstruction plans is a problem for } \\
\text { infrastructure development } \\
\text { 2- Organizational management and } \\
\text { administrative ownerships are the } \\
\text { obstacles in the reconstruction } \\
\text { process and city development after the } \\
\text { war }\end{array}$ \\
\hline & Social & Immigration & $\begin{array}{l}\text { 1- Unwillingness to return towards some } \\
\text { original residents and replace with } \\
\text { new settlers created social problems in } \\
\text { neighborhoods of the city } \\
\text { 2- New immigrant job seekers changes } \\
\text { the social context of the city }\end{array}$ \\
\hline
\end{tabular}

(Source: Interview transcripts)

Table 2: Measure of central tendency of urban problems after reconstruction

\begin{tabular}{llllr}
\hline \multicolumn{1}{c}{ Persistent problems } & Category & Mean & Median & $\begin{array}{c}\text { Std. } \\
\text { Deviation }\end{array}$ \\
\hline $\begin{array}{l}\text { 1-New-made buildings versus old } \\
\text { and damaged ones }\end{array}$ & Physical & 3.71 & 4 & 0.68 \\
\hline $\begin{array}{l}\text { 2-Abandoned land and } \\
\text { dilapidated buildings }\end{array}$ & Physical & 3.83 & 4 & 0.77 \\
\hline $\begin{array}{l}\text { 4-Implementation of } \\
\text { reconstruction plans and } \\
\text { undeveloped infrastructures }\end{array}$ & Executive & 2.49 & 3 & 0.63 \\
\hline $\begin{array}{l}\text { 5-Immigration and social } \\
\text { demographic changes }\end{array}$ & Social & 4.20 & 4 & 0.90 \\
\hline
\end{tabular}

(Source: Survey, 2013) 
The quantitative survey also determined the rank of importance of persistent urban problems. Referring to the percentages of the items, the majority $(72 \%)$ of the respondents evaluated the immigration and demographic change as the main problem (ranks 4 and 5), followed by abandoned lands and dilapidated buildings (66\%), and mismatched facades due to the differences between new buildings and old buildings (63\%).

The overall score for each item in Table 2 reveals that the most important problems in the category of rehabilitation were related to the social aspects of immigration, with a mean of 4.2 $(\mathrm{SD}=0.90)$ and a median of four. The second and third most important problems were physical aspects. Abandoned land and ruined buildings, with a mean of $3.83(\mathrm{SD}=0.77)$ and a median of four. The third most important problem, with a minor difference to the second-ranked problem, was the mismatching of urban facades due to differences between new and old buildings, with a mean of 3.71 $(\mathrm{SD}=0.68)$ and a median of four.

\section{KEY FINDINGS AND DISCUSSIONS}

The results of the present paper emphasize the significance of the reconstruction strategy and priorities in the urban reconstruction. Based on the analysis, physical and social items were categorized as the reconstruction problems and priorities in KhorramShahr

Relocation was the first proposed policy for resettlement plan of Khorram-Shahr that most of the residents opposed this plan. According to the United Nations (2008), relocation is the last solution for rebuilding: relocation or resettlement should be avoided unless it is essential for reasons of safety. Displacement is likely to exacerbate the impacts of a tragedy on wellbeing, social connections and livelihoods, in both rural and urban environments. Due to mass destruction in a post-war city or concerns about the prevention of future losses, authorities and policy-makers sometimes explore the feasibility of establishing the war-torn city in a new location during the reconstruction process, with an eye toward modernization a new city (Calame, 2005). Groat and Wang (2013) stress the sense of place for the original people as relocation is not just a physical act. As relocation depends on social behaviours and cultural customs, it should be explored using scientific methods making reference to the original city's background in order to determine the relocation criteria. Furthermore, displacement must always be voluntary and authorities should respect the rights of people to choose a location to rebuild their lives. In the case of Khorram-Shahr in Iran, for example, the relocation plan for the city was never implemented by the government due to residents' resistance (Rabani, 1997).

In terms of housing policy, the authorities in Khorram-Shahr limited their involvement to the supervision of quality without any detailed plan for people who were assigned to rebuild their homes. In regard to the activities in the reconstruction period, Couch et al. (2011) argue that the efforts of most government and semi-government sectors are needed, particularly in relation to the housing policy. Taheri and Tomlinson (2013) also emphasise that post-disaster reconstruction cannot be implemented without support from the government sector, such as providing mass housing and infrastructure. Similarly, Félix et al. (2014) highlight the government's role in reconstruction because of the large-scale destruction and the need for mass housing projects after disasters.

The next most important concern in a resettlement plan is infrastructure as an essential need for post-war returnees. According to Hass et al. (1977), the process of restoring infrastructure is divided into two phases, namely, replacement and developmental reconstruction. Andersen (2003) and Gore and Fischer (2014) stress that infrastructure is often the first step in the restoration of post-war cities, as it provides the essential resources needed for the urban revitalisation. During the resettlement process in Khorram-Shahr, infrastructure supplies vital resources. The reconstruction of infrastructure in Khorram-Shahr and the surrounding area remained limited to the restoration stages rather than the development phase in the second phase of resettlement.

Urban rehabilitation in Khorram-Shahr was impeded by the social aspects as the main issue identified by the local residents. Non-local settlers in the neighbourhoods of Khorram-Shahr changed the demographic population and cultural context of the original inhabitants. Regarding the social aspects of rehabilitation, Elmasri (1989) claims that physical reconstruction should help in healing the social division, which is the more difficult task of rehabilitation. Cuny et al. (1983), Geipel (1991) and Rabani (1997) also reveal that demographic changes and social impacts are inseparable aspects of the resettlement process. As they point out, war causes many changes in people's day-to-day lives, and demographic change is an influential aspect with a significant impact on the rehabilitation process. In the 
case of Iran, the issue of immigration was compounded by the government's strategy to accelerate returns to post-war regions on the basis of political considerations. Owing to new opportunities in the reconstruction period, a new wave of immigrants from other parts of the country replaced some pre-war original residents in the neighbourhoods of Khorram-Shahr, leading to change in the sociocultural context of the city. In regard to the findings of the present research, demographic changes and the consequences of non-indigenous settlement remained ongoing obstacles in the social aspects of urban reconstruction in Khorram-Shahr.

\section{CONCLUSION}

The results reported in this paper emphasise the significance of the resettlement policy in post-war reconstruction. The present research discussed the process of post-war restoration and explored the resettlement plan in Khorram-Shahr. The persistent urban defects experienced in Khorram-Shahr were explored through interviews with experts and feedback from local residents. It was found that the reconstruction policy focused on providing basic life conditions and encouraging people to return to Khorram-Shahr for social and security reasons. However, the long-term consequences of post-war resettlement and housing policy in urban areas remain unresolved twenty years after the reconstruction period. The research reported in this paper demonstrated that most of the respondents were concerned about social problems, with the majority ranking non-local settlers as the most significant problem in the neighbourhoods of Khorram-Shahr.

The results revealed that urban reconstruction after a war is necessary and must focus on vital physical priorities (e.g., housing, utilities); nevertheless, this approach is not adequate on its own. Demographic changes and the consequences of nonindigenous settlement have created social problems in the post-war period in the urban areas of KhorramShahr. Migration and the consequences of new settlers in the reconstruction process should be considered by the urban planners, urban designers and authorities in the resettlement plan. These results and the evaluation of the policy framework for reconstruction can offer significant contributions to government authorities and urban planners regarding aspects of the future infrastructure development and housing policy in Khorram-Shahr and similarly affected post-war cities.

\section{REFERENCES}

Amirahmadi, H. (1987). Destuction and reconstruction: A Strategy for the wardamaged areas of Iran. Disasters, 11(2), 134$147 . \quad$ doi: $\quad 10.1111 / \mathrm{j} .1467-$ 7717.1987.tb00628.x

Andersen, H. S. (2003). Urban Sores: on the interaction between segregation, urban decay and deprived neighbourhoods. Aldershot: Ashgate.

Bruchhaus, E. M. (2002). Post-war recovery the "triple r" approach in theory and practice. $D+C$ Development and Cooperation, 3(19-21).

Calame, J. (2005). Post-war reconstruction: concerns, models and approaches. Macro Center Working Papers.

Couch, C., Sykes, O., \& Börstinghaus, W. (2011). Thirty years of urban regeneration in Britain, Germany and France: The importance of context and path dependency Progress in Planning, 75, 1-52.

Creswell, J. W., \& Clark, V. L. P. (2011). Designing and conducting mixed methods research. Thousand Oask: Sage Publication Inc.

Cuny, F., Abrams, S., \& America, O. (1983). Disasters and development. New York: Oxford University Press.

El-Masri, S. (1989). Displacements and reconstruction: The case of west Beirut Lebanon. Disasters, 13(4), 334-344. doi: 10.1111/j.1467-7717.1989.tb00727.x

Félix, D., Branco, J. M., \& Feio, A. (2014). Temporary housing after disasters: A state of the art survey. Habitat International, 40(0), 136141.

Geipel, R. (1991). Long-term consequences of disasters: The reconstruction of Fruili, Italy in its international context. New York: Springer-Verlag.

Gore, T., \& Fischer, T. B. (2014). Uncovering the factors that can support and impede postdisaster EIA practice in developing countries: The case of Aceh Province, Indonesia. Environmental Impact Assessment Review, 44(0), 67-75. doi: http://dx.doi.org/10.1016/j.eiar.2013.09.001

Groat, L., \& Wang, D. (2013). Architectural research methods. New Jersey: John Wiley \& Sons Inc.

Haas, J. E., Kates, R. W., \& Bowden, M. J. (1977). Reconstruction following disaster. Cambridge: The MIT Press Environmental Studies Series. 
Hilāl, A. D. (1981). The Iraq-Iran War: Issues of Conflict and Prospects for Settlement. New Jersey: Center of International Studies, Woodrow Wilson School of Public and International Affairs, Princeton University.

Hooglund, E. (1989). The Islamic republic at war and peace. Middle East Report, 156, 4-12.

Kerlinger, F. N., \& Lee, H. B. (2000). Foundations of behavioral research. San Diego: Harcourt College Publishers.

Knight, A., \& Ruddok, L. (2008). Advanced research methods in the built environment (Vol. 3). Chennai India: Blackwell Publishind Ltd.

Kumar, K. (1997). Rebuilding societies after civil war: Critical roles for international assistance. London: Lynne Rienner Publishers.

Lizarralde, G., Johanson, C., \& Davidson, C. (2010). Rebulding after disaster. London: Spon Press.

Motawaf, S. (1989). Reconstruction policy and implemention in war disaster,case study Khorramshahr,Iran. Paper presented at the 3rd International conference on reconstruction of war-damaged areas. Tehran: Tehran University Press

Najarian, L. M., Goenjian, A. K., Pelcovttz, D., Mandel, F., \& Najarian, B. (1996). Relocation after a disaster: Posttraumatic stress disorder in Armenia after the earthquake. Journal of the American Academy of Child \& Adolescent Psychiatry, 35(3), 374-383.

Pedersen, M. H. (2003). Between homes:Post-war return, emplacement and the negotiation of belonging in Lebanon. UNHCR The UN refuge agency (Working Paper No. 79).

Rabani, R. (1997). Sociology of Reconstruction. Paper presented at the 3rd International Conference on Reconstruction of the War-Damaged Areas. Tehran: Tehran University Press.

Taheri Tafti, M., \& Tomlinson, R. (2013). The role of post-disaster public policy responses in housing recovery of tenants. Habitat International, 40(0), 218-224. doi: http://dx.doi.org/10.1016/j.habitatint.2013.0 5.004

United Nations. (2008). Transitional settlement and reconstruction after natural disasters .New York: UN/OCHA.

Yassin, N. (2012). Beirut. Cities, 29(1), 64-73. doi: http://dx.doi.org/10.1016/j.cities.2011.02.00 1

Zargar, A. (1989). Settlement reconstruction after war. Workshop Report, 16-18 May 1989. Disasters, 13(3), 263-267. doi: 10.1111/j.1467-7717.1989.tb00716.x 